more or better resources. Planning groups have used the data to estimate the type and size of a disturbed behaviour unit and to outline future community housing needs.

Finally, it is worth noting that, although prior to the survey many people throughout the hospital had been informally aware of many of the facts which were demonstrated, no significant change in practices or organisation of the wards had occurred. The presentation of relatively objective information in the form of simple graphs allowed these points to be grasped and accepted in a way which may have been impossible on the basis of personal opinion alone. The survey had, in a sense, held up a mirror to the institution and, in doing so, had helped to begin a process of change which is still continuing.

Since 1984, the survey has been repeated annually on a specific date, allowing the additional advantages of the identification of longitudinal trends and the comparison of individuals or groups over time. As well as initiating change, it is evident that survey information still has a significant role to play in providing feedback on the results of planning decisions and in ensuring that the system continues, as far as possible, to meet the needs of those whom it is designed to serve.

REFERENCES

'Wing, J. J. \& Brown, G. W. (1970) Institutionalism and Schizophrenia. Cambridge: Cambridge University Press.

${ }^{2}$ Georgiades, N. J. \& Phillimore, L. (1975) The myth of the heroinnovator and alternative strategies for organisational change. In Behaviour Modification with the Severely Retarded (eds. C. C. Kiernan and F. D. Woodford). Amsterdam: Associated Scientific.

${ }^{3}$ Ryan, P. (1979) Residential care for the mentally disabled. In Community Care for the Mentally Disabled (eds. J. K. Wing and R. Olsen). Oxford: Oxford University Press.

${ }^{4}$ BAKER, R. \& HALL, J. N. (1983) Users Manual for REHAB. Aberdeen: Vine.

This is the last of a series of four papers published in the Bulletin on rehabilitation developments at Severalls Hospital.

\title{
Fund for Memorial to Dr Michael York-Moore
}

In tribute to Michael York-Moore's commitment to the welfare of people with mental handicap and their families and of his association with and contribution to the British Institute of Mental Handicap, the Institute wishes to establish a memorial fund in his name. Michael York-Moore had wide interests in the field of mental handicap which extended beyond his own particular specialism in medicine. He was aware of the diverse, important contributions which different service disciplines, families, the public and people with mental handicap themselves could make to changing the position of people with mental handicap in our society. He had a particular empathy for the needs of families and children with mental handicap living at home.

The proceeds of this appeal will be held in trust by BIMH and the interest used to fund an initiative which would benefit Families and Children with Mental Handicap. This initiative, to be determined by appointed Trustees, would take any of the following forms. It could:
(1) fund travel by a parent or professional to learn about effective ways for working with families;

(2) fund an invited presentation by a person with international repute for his or her work with families;

(3) fund acquisition to the BIMH Information and Resource Service of resource materials designed for families or professionals working with families;

(4) support the organisation of a conference or other forms of information exchange designed for parents.

BIMH will establish the Trust and the Trustees following legal advice to implement the remit set out above. The purpose of the Trust has the full support of Rosemary York-Moore.

Please send donations to establish this fund in memory of Michael York-Moore to: Administrator, British Institute of Mental Handicap, Wolverhampton Road, Kidderminster, Worcs. DY10 3PP.

Cheques should be made payable to BIMH. 